\title{
Investigating Factors Influencing Customer Online Buying Satisfaction In Gauteng, South Africa
}

\author{
Sharon Rudansky-Kloppers, University of South Africa, South Africa
}

\begin{abstract}
Online shopping has increased significantly worldwide in the last few years. South Africa is no exception, but although this country has experienced an increase in online shopping, it seems to lag behind the rest of the world where this development is concerned. Research into the factors which influence customer online shopping satisfaction is thus imperative in order for South African retailers to develop the correct strategies for online sales. With this information, they can convert potential customers into real customers and retain them.

This research investigates the factors which influence customer online buying satisfaction in the Gauteng province of South Africa. The researcher made use of secondary research to construct a model of factors influencing online customer satisfaction and then tested the model among South Africans living in the Gauteng province. A sample of 111 online shoppers was used and quantitative research was conducted by means of a structured questionnaire. It was found that convenience, delivery, and time saving were viewed by customers as the most important reasons for buying online, while branding was viewed as the least important factor. The research results confirmed the model developed by the researcher. Results of the study, as well as recommendations for future research, are presented.
\end{abstract}

Keywords: Online Shopping; Customer Satisfaction; Technology Factors; Shopping Factors; Product Factors; Logistic Factors

\section{INTRODUCTION}

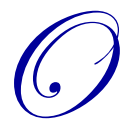

nline shopping involves the sale and purchase of products and services over the internet and has become increasingly popular in South Africa during the last few years. As the internet connectivity in South Africa increased from $10 \%$ in 2010 to $35 \%$ in 2012, more and more shoppers have turned to online shopping (Anonymous, 2013).

Research conducted by the Digital Media and Marketing Association (DMMA) and Echo Consultancy estimates the total internet population in South Africa in 2013 to be almost 14 million users. This represents 39\% of the adult population (Cinman, 2013). In South Africa, 58\% of the internet population shop online and $75 \%$ of these shoppers have done so in the previous three months. This is significantly higher than the $18-24 \%$ internet users in other African countries, such as Kenya, who make use of online shopping (Cinman, 2013).

Much research has been conducted on on-line buying in the world, but limited research has been conducted in South Africa. Prior international research has focussed on topics such as E-service quality, E-customer satisfaction, E-loyalty, website design, system satisfaction, information satisfaction, and so forth. Because of the unique differences between African countries and other countries in the world, the results of research done in Africa regarding online shopping might differ significantly from those done in the rest of the world. Research has been done inter alia on online apparel shopping behaviour of South African professional women (Jacobs \& De Klerk, 2010), cybershopping concerns of the South African consumer (North, Mostert, \& Du Plessis, 2003), the fastest 
growing categories of online sales (Goldstuck, 2013), online shopping trends (Wealthwisemag, 2013), online spending habits (Wilson, 2013), and so forth. It is imperative for businesses selling their products and services online to know more about the factors which influence the satisfaction of the customers who make use of online shopping. With this information they can convert potential customers into real customers and retain them.

This study focusses on the factors which influence online customer satisfaction of online shoppers in Gauteng, South Africa. The Gauteng province has been chosen because it is considered the commercial heart of the country. It contributes more than $33 \%$ to the national economy and $10 \%$ to the GDP of the entire African continent (South Africa.info, 2014).

\section{RESEARCH PROBLEM}

According to Forrester, American retailers generated online sales of $\$ 231$ billion in 2012. It is estimated that E-sales (sales by means of computer networks) will overtake normal retail sales in the next five years and reach $\$ 370$ billion in 2017. In Western Europe, internet sales is even higher at $€ 112$ billion and it is estimated that it will be approximately $€ 91$ billion in 2017 (Watson, 2013). According to Kloppers (2013), online shopping in South Africa is five to seven years behind that in Britain, America, Europe, and Australia.

Euromonitor International indicates that South Africa lags behind most of its peers in the Brics economic grouping when it comes to online retail sales (Maake \& Shevel, 2013). In South Africa, 0.9\% of retail sales are conducted online, compared to $11 \%$ in Brazil, $4.2 \%$ in Russia, and $10.7 \%$ in China. Retail online sales in South Africa is slightly better than the $0.7 \%$ in India (Maake \& Shevel, 2013). According to World Wide Worx, many retailers do not do enough research and do not spend enough time developing strategies before they go online (Maake \& Shevel, 2013). In South Africa, Pick n Pay and Woolworths were amongst the first companies to dominate online retail, but they did not realise how expensive it would be to keep frozen products until point of delivery and they underestimated the cost of rectifying errors. These two grocery giants derive less than $1 \%$ of their total sales from internet retailing (Maake \& Shevel, 2013).

Research by Urban Studies indicates that in the next few years South African retailers will have to do everything possible to catch up with online shopping in the rest of the world (Kloppers, 2013). They will have to provide the right products and infrastructures in order to provide world class online shopping as an additional sales channel. Research into the factors which influence online shopping satisfaction is thus imperative in order for South African retailers to develop the correct strategies for online sales.

\section{LITERATURE BACKGROUND}

\section{Online shopping}

Online, or E-shopping, enables customers to make use of an online store to search for products and services, order the selected products and services, choose a delivery method, indicate an address and date, and pay for them. All the products and services of these online stores are described through text, with photographs and multimedia files. On receipt of an order, the online store sends an electronic confirmation to the customer. In recent research done by MasterCard, the products mostly purchased online by South African shoppers are products such as air tickets, travel, and accommodations (Goldstuck, 2013), followed by concert and event tickets and coupons from group-buying sites.

The four common components of an online shop are the storefront, the shopping cart, the payment process, and the order fulfilment (emarketing dictionary, 2014). The storefront, or online store, where customers do their shopping on the website, provides different types of information to consumers, including product types, product descriptions, instructions, demonstrations, how-to guides, safety procedures, product reviews from other consumers, contact information, and store policies. The shopping cart allows customers to select and store multiple products that they want to purchase. The customer clicks the "add to shopping cart" button and the product is stored in the digital shopping cart. The third component is the payment process. This system allows the customer to select a payment method (for example, credit card payment or Electronic Funds Transfers (EFT)) and it gathers payment information 
(such as credit card information) and processes or records the payment information. The final component; namely, order fulfilment, is the process of obtaining the products the customer has ordered, shipping or delivering them, and keeping delivery tracking information.

According to Watson (2013), online shoppers in South Africa mostly make use of smart phones to do their shopping. The use of tablets is, however, increasing. Today, about $40 \%$ of online shoppers are using tablets compared to the $30 \%$ in 2012 . Nearly $70 \%$ have used their tablets for online purchases.

There are many advantages involved with online shopping. One of the most obvious benefits to both the consumer and the online business is that of convenience. Customers do not have to physically go to a store if the store offers e-shopping. They can simply make use of a computer or mobile phone to do their shopping in the convenience of their home or workplace. In research conducted by Jana on more than 600 consumers, it was found that South Africans cited the convenience factor as the biggest advantage to shopping online (wealthwisemag.com, 2013). There is also the time-saving benefit which online shopping offers to customers. Shoppers do not have to take the time to travel to a store, drive through heavy traffic, or stand in long queues to pay. They also do not have to restrict their shopping to business hours since online shops are open 24 hours a day. Compared to physical shopping, browsing online can also be done much quicker. It allows customers to quickly compare similar products and prices through visiting multiple stores online (Koble, 2014). In this way, they can buy the product with the best price or quality. Because of the many competitors who offer online shopping to customers, these businesses often offer discounts and special offers to draw customers to their sites. In the MasterCard survey of online South African shoppers, it was found that $65 \%$ of the respondents indicated that promotional offers, discounts or free gifts are important when choosing an online retailer (Goldstuck, 2013). Online shopping also allows people from anywhere in the world to do online shopping at a particular store. This is convenient to the customer, and also provides increased sales for the business. Besides all these benefits, the customer can also choose to have the product delivered to his/her door.

A major reason why many consumers do not want to shop online is because of the fear of fraud or theft with credit card purchases, the fear of hackers and buying from dishonest sellers. In the study by Jana, it was found that $14.4 \%$ of South Africans indicated perceived lack of security as an obstacle to buying products online (wealthwisemag.com, 2013). Although security tips are provided in most cases, this remains a definite disadvantage of online shopping. Another disadvantage is that the shopper cannot physically see or try the product in order to judge whether its actual characteristics match the stated ones on the website. Logistical factors are often viewed as disadvantages of shopping online. Shipping or delivery costs could, for instance, be quite high. Many online businesses offer "free" shipping or delivery, but only if the cost of the order is a specific, minimum amount. The product could also be defective or damaged when it arrives, which will involve returning of the product to the seller. The customer is often responsible for any return costs. Another logistical disadvantage of online shopping is the longer time, compared to physical shops, it takes to receive the products after the customer has paid. The customer has to wait for the product to be packed, shipped and delivered. In the study by Jana, this was seen as the largest obstacle (37.86\%) by South African consumers for buying products online (wealthwisemag.com, 2013). Online support is often limited or non-existent for products purchased online and no personal interaction or relationship can take place or be built between the online shop and the customer, as is often the case when dealing with retail stores.

According to Duncan (2013), the percentage of internet users shopping online grew to $58 \%$ in 2012, compared to $53 \%$ in 2010 and $44 \%$ in 2009. Research by World Wide Worx indicates that R3.6 billion was spent on online retail (traditional retail products bought online) in 2012 (Goldstuck, 2013). It is expected that this will rise by about 25\% in 2013. Unfortunately, the number of people purchasing online (approximately 2.2 million) has barely changed. The MasterCard survey shows a slight decline (58\% to 54\%) in online shoppers in 2013 (Goldstuck, 2013). The study does, however, indicate that $91 \%$ of South Africans who shop online are very satisfied with their overall experience. The decrease in online shoppers can be attributed to the economic slowdown and increased inflation (Anonymous, 2013). Nevertheless, research indicates that growth in retail shopping among the higher income groups is at more than 60\% (Maake \& Shevel, 2013). It is also expected that by 2018, online purchasing could increase to more than R18 billion, which means it will make up between $2 \%$ and $3 \%$ of total retail sales (Kloppers, 2013). 
South Africa's internet economy made up 2\% of the economy in 2011 but is expected to increase its share to $2.5 \%$ by 2016 (Goko, 2014). A survey of South African internet users indicates that people who have spent at least five years using the internet are 50\% more likely to shop online (Duncan, 2013). Research by the Digital Media and Marketing Association (DMMA) indicates that almost one in five internet users were likely to spend more than five hours a day on Facebook and, in general, they respond to animated online advertisements with no video or sound. It was found that $39 \%$ of respondents actively look for brands on social networks, while $72 \%$ said they followed the brands they liked on social networks (Goko, 2014). In the United States, over 70\% of online purchase decisions are informed by reviews on social networking sites like Facebook and Twitter, as well as customer reviews on blogs or ecommerce sites (Anonymous, 2013). Although South African online shoppers do not use social networks to this extent yet, it looks as if they are moving in this direction.

In South Africa, $42 \%$ of online shoppers buy online at least once a month and $47 \%$ do their research online but then purchase in a retail store. Research indicates that the category of people who earn R20,000 per month has less online shoppers than those who earn more. The highest percentage of online shoppers earn more than R50,000 per month and the median income of online shoppers is R38,000 per month (Kloppers, 2013).

Traditional retail shops will never disappear, but online shopping will increase in the future. It is therefore imperative for these online retailers to make it easy and pleasant for shoppers to do their purchasing online.

\section{MODELS OF FACTORS INFLUENCING ONLINE CUSTOMER SATISFACTION}

Any business aims to achieve customer satisfaction among its customers. This is no different for online stores. Dissatisfied customers will not make use of the online store again and might be discouraged from buying online in the future.

Brink and Berndt (2004) define customer satisfaction as the degree to which an organisation's product or service matches up to the expectations of the customer. It is thus the extent to which the consumer's perceptions of the online shopping experience confirm his/her expectations. If the customer's experience of the product or service exceeds his/her expectations of the product or service, the customer will be satisfied. Customer satisfaction is of extreme importance in establishing long-term customer relationships. It has been found that a satisfied customer has a positive purchase intention, such as a repurchase, positive word-of-mouth, and loyalty in the long-term (Byambaa \& Chang, 2012). An understanding of the factors influencing customer satisfaction is thus extremely important.

Various models of factors influencing customer satisfaction have been developed. Among them is Kano's model of customer satisfaction which distinguishes between three types of product requirements influencing customer satisfaction in different ways. These are must-be-requirements (if not met, the customer will be very dissatisfied), one-dimensional requirements (the higher the level of fulfilment, the higher the customer's satisfaction and vice-versa) and attractive requirements (the product criteria which have the greatest influence on how satisfied a customer will be with a given product) (Sauerwein, Bailom, Matzler, \& Hinterhuber, 1996).

Another model of customer satisfaction is the well-known SERVQUAL, which is a multi-item scale developed to assess customer perceptions of service quality (Shaikh, 2009). The SERVQUAL instrument enables organisations to ascertain perceived service quality by calculating the gap between customers' expectations of the service they would receive and their perceptions of the actual service delivered (Chen, Yeh, \& Chen, 2011).

SERVQUAL was developed in 1985 by Berry, Parasuraman, and Zeithaml (Ahuja, Mahlawat, \& Masood, 2011). The original SERVQUAL tool consisted of 10 criteria and dimensions through which service quality could be assessed; namely, competence, communication, credibility, security, understanding, tangibility, accessibility, courtesy, reliability, and responsiveness (Prasad \& Shekar, 2010). These ten criteria were later integrated into only five dimensions; namely, reliability, assurance, tangibility, empathy, and responsiveness (Zeithaml, Bitner, \& Gremler, 2006).

The various models of customer satisfaction that have been developed in the past are mostly focussed on satisfaction with the products and services of traditional retail stores and are not always applicable to online shopper satisfaction. 
Various models have thus been developed to identify the factors influencing online customer satisfaction. In this study, some of these models were investigated and the information was used to develop a model that was tested among South Africans living in the Gauteng province.

Alam and Yasin (2010) developed a model which identified five factors influencing online shopping satisfaction in Malaysia; namely, website design, reliability, product variety, time saved, and delivery performance. When this model was tested, they found that website design, reliability, product variety, and delivery performance were the key variables influencing online shopping. Their results indicate that the time saved did not have a significant effect on satisfaction of Malaysian shoppers.

Guo, Ling, and Liu (2012) developed a model of factors influencing online shopping satisfaction in China. They identified eight influencing factors on customer satisfaction; namely, website design, security, information quality, payment method, e-service quality, product quality, product variety, and delivery service. They found that all eight of these factors are positively related to consumer satisfaction when buying online.

Schaupp and Bèlanger (2005) designed a model which identified three categories of determinants that could affect online shopper satisfaction. They are technology factors which include security, usability and site design, and privacy; shopping factors which include convenience, trust and trustworthiness, and delivery; and product factors which consist of merchandising, product value, and product customisation. Their results indicate that the three most important attributes to consumers for online shopping satisfaction are privacy, which is a technology factor; merchandising, which was classified as a product factor; and convenience, which is a shopping factor. These are followed by trust, delivery, usability, product customisation, product quality, and security.

Byambaa and Chang (2012) designed and tested their model of factors influencing online satisfaction of buyers of electronic airline tickets. These factors are ease of use, information quality, website design, payment security, and interactivity. They found that three of these factors were significant in affecting satisfaction of online e-ticket shoppers; namely, interactivity, payment security, and ease of use.

After reviewing the above-mentioned models and the information collected about online shoppers in South Africa, the researcher developed a framework indicating the factors influencing customer satisfaction of online shoppers. This framework is indicated in Figure 1 and was used to test the factors influencing online satisfaction of consumers in Gauteng, South Africa. The framework is based on the three categories used by Schaupp and Bèlanger, but the researcher has added another category; namely, logistics, and has also added additional factors to each of the existing categories.

The technology factors in Figure 1 refer to the qualities of the website that ensure functionality of the site and include security features, website ease of use, user-friendly website, and privacy. Security refers to the website's ability to protect the customer's personal information collected during electronic transactions from unauthorised use of disclosure. Website ease of use and user friendliness refers inter alia to the website's speed, navigation capability, simple search paths, and interactivity. Privacy refers to the willingness to share information over the Internet that allows for the conclusion of a purchase (Bèlanger, Hiller, \& Smith, 2002).

The shopping factors in Figure 1 refer to customers' feelings and perceptions during and after the shopping experience (Schaupp \& Bèlanger, 2005). Quite a few factors were identified here; namely, convenience, trustworthiness of information, ease of payment, time saving, more online information, lower price, and value for money. Convenience entails the ease of shopping, finding a product, post-purchase service, complete contact information, and minimisation of overall shopping effort (Schaupp \& Bèlanger, 2005). Trustworthiness of information refers to the customer's willingness to accept the information provided by the online store about the product, price, and payment. Ease of payment refers to aspects such as ease of understanding the payment policy and speed at which payment transaction will take place. Time saving also refers to, among others, the speed of the transaction, the time saved in not having to travel to retail stores, and in not having to stand in long queues at these stores. More online information entails the instructions, demonstrations, how-to guides, safety procedures, product reviews, and store policies that are available on the store website. Lower price refers to the belief or perception by shoppers that products bought on the internet are cheaper than those purchased at a retail store. The last shopping 
factor in the model; namely, value for money, is the belief that purchasing products on the internet provides value for money (Schaupp \& Bèlanger, 2005).

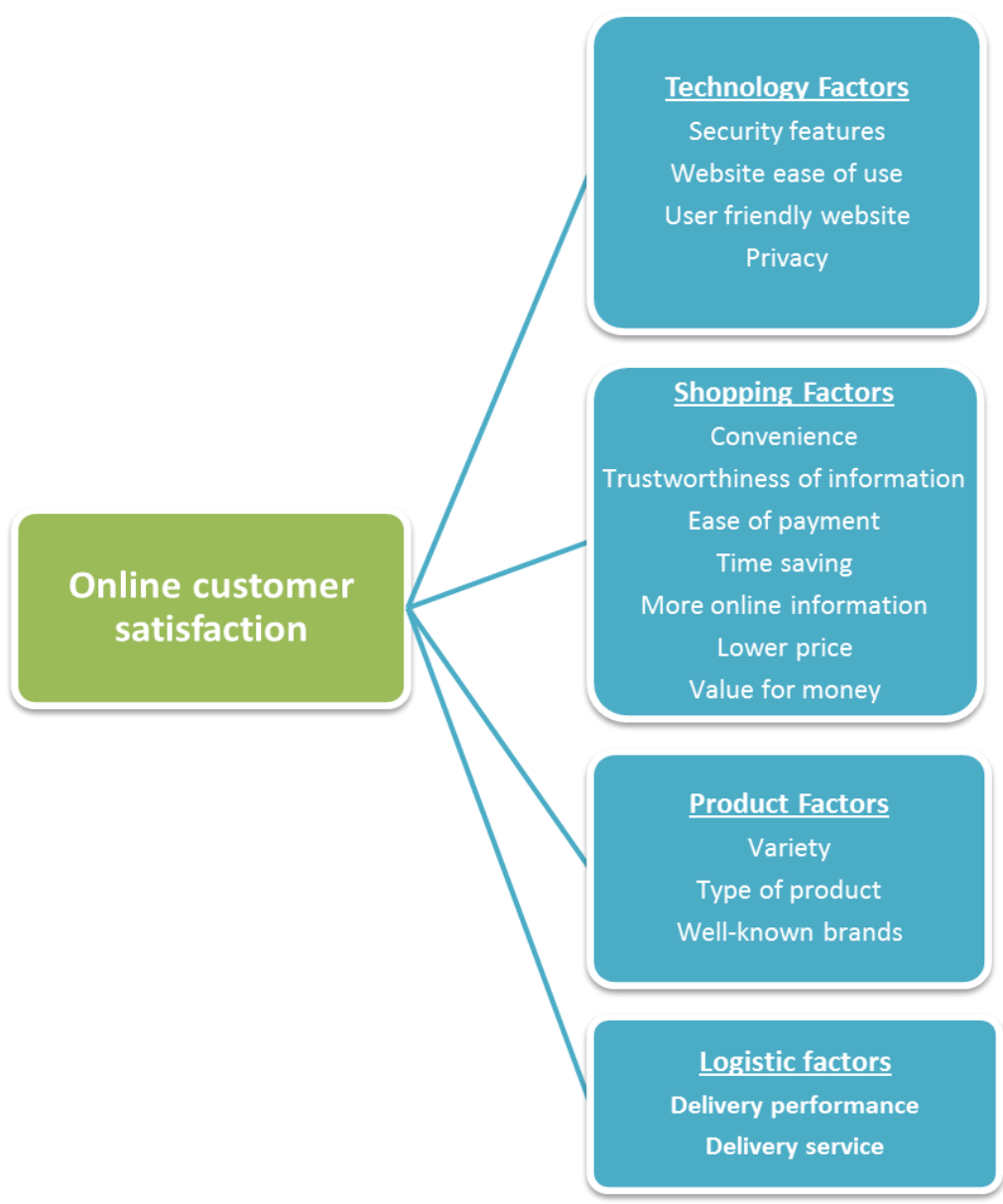

Figure 1: Factors Influencing Online Shopping Satisfaction

Product factors, as indicated in Figure 1, pertain to the quality of the product or service for sale (Schaupp \& Bèlanger, 2005). They refer to the product variety, type of product, and well-known brands which entail the wide range of products and services that can be purchased online, as well as the brands that are offered.

Logistic factors refer to the delivery of the products and services. They refer to delivery performance and service which refer to aspects such as speed of delivery, tracking and tracing, accuracy of delivery and communication with customers regarding possible delays in delivery. In this article the researcher investigates whether the factors in the model developed do, in fact, influence the online shopping satisfaction of shoppers in Gauteng.

\section{RESEARCH OBJECTIVES}

The primary objective of this research was to investigate factors that influence customer online buying satisfaction. Secondary objectives were to determine whether technology factors such as security, website ease of use, and privacy, influence customer online shopping satisfaction; whether shopping factors, such as convenience, trustworthiness, ease of payment, time saving, price, and value for money, affect customer online shopping satisfaction; whether product factors, such as variety, type of product, and well-known brands influence customer online buying satisfaction; and whether logistic factors, such as delivery performance and service, affect customer online shopping satisfaction. 


\section{RESEARCH METHODOLOGY}

Both primary and secondary research was conducted for this study. Secondary data are information collected for other research projects or problems and primary data are that which are specifically collected to address the research objective (Tustin, Ligthelm, Martins, \& Van Wyk, 2010).

The study involved quantitative research which generally involves the collection of primary data from large numbers of individuals with the intention of projecting the results to a wider population. The aim is to generalise the specific population based on the results of a representative sample of that population (Tustin, Ligthelm, Martins, \& Van Wyk, 2010).

\section{Sampling}

The target population included all online shoppers in Gauteng, South Africa. The survey area of the research included Pretoria, Johannesburg, and the East Rand. The three telephone directories covering these areas were used as a sampling frame in order to conduct computer-assisted telephone interviews (CATI) with the survey population. A quota-based random selection of the household entries in these telephone directories was done. A screening question helped to select only persons who had conducted online buying during the past 12 months and who were prepared to participate in the survey. The realised sample consisted of 111 respondents.

\section{Data Collection}

To ensure content validity, a structured questionnaire was constructed by a research team, including a statistician, and discussed by the members of the research team to assess whether each measurement question in the questionnaire was essential.

The initial questionnaire was pre-tested telephonically on households in the survey area. Pre-testing was an important step in identifying participant interest, to ensure that the questions were not ambiguous, that the continuity and flow of the questionnaire was correct, and that skip instructions were clear (Blumberg, Cooper, \& Schindler, 2011).

Interviews were conducted from $14 \mathrm{~h} 00$ to $19 \mathrm{~h} 00$ on weekdays and from $9 \mathrm{~h} 00$ to $13 \mathrm{~h} 00$ on Saturdays. Respondents were assured of their anonymity and confidentiality and all information provided was treated as confidential and used solely for the purpose of the study.

Categories covered in the questionnaire included frequency of online buying, type of products purchased, reasons for buying online, time of buying online, sources of reference for buying online, satisfaction with online shopping and demographic information.

\section{RESEARCH RESULTS}

The demographic profile of the respondents is indicated in Table 1.

\begin{tabular}{|c|c|c|c|c|c|}
\hline Demographic criteria & Category & $\%$ & Demographic criteria & Category & $\%$ \\
\hline \multirow{4}{*}{ Age group } & $18-29$ years & 19,8 & \multirow{3}{*}{ Gender } & & \\
\hline & $30-49$ years & 48,6 & & Male & 41,4 \\
\hline & $50-64$ years & 21,6 & & Female & 58,6 \\
\hline & 65 and older & 9,9 & & & \\
\hline \multirow{5}{*}{$\begin{array}{l}\text { Highest level of } \\
\text { education }\end{array}$} & Primary (Grade 1-7) & 0,9 & \multirow{5}{*}{$\begin{array}{l}\text { Household income } \\
\text { per month } \\
\text { after taxes }\end{array}$} & Less than R10 000 & 15,3 \\
\hline & Secondary (Grade 8-12) & 19 & & R10 $000-$ R30 000 & 40,5 \\
\hline & Completed diploma & 24,3 & & More than R30 000 & 24,3 \\
\hline & Completed degree & 35,1 & & Don't want to divulge & 19,8 \\
\hline & Post-graduate qualification & 19,8 & & & \\
\hline
\end{tabular}


The majority of respondents (70.2\%) fall in the 30-64 year age group, while 19.8 percent fall in the 18-29 age category and only 9.9 percent are older than 65 . Where the gender of the respondents is concerned, 41.4 percent were male, while the majority (58.6\%) were female. Regarding education, 79.2 percent of the respondents have post-school qualifications, with $54.9 \%$ of the respondents having completed at least a degree.

The majority $(40.5 \%)$ of the respondents fall in the R10,000-R30,000 per month income group, while the second most respondents $(24.3 \%)$ fall in the group which earns more than R30,000 per month, thus 64.8 percent of the respondents earn more than R10,000 a month.

The mean and median values of factors influencing customer online buyer satisfaction are indicated in Figure 2. The mean values range between 3.26 and 4.59 and the median values between 3 and 5, indicating that, on average, respondents tend to rate the factors as important to very important. The statements with the highest and lowest mean values, respectively, were convenience and well-known brands, which indicates that convenience, delivery and saves time are thus seen as the most important factors (mean values of 4.59, 4.32, and 4.28, respectively and a median of 5) and well-known brands is the least important.

As the mean and median values are fairly close to each other, it indicates that the distribution of the values are fairly symmetric, except for convenience, saves time, and delivery, where the median values were higher than the mean values, indicating that the mean has been influenced by a few low scores.

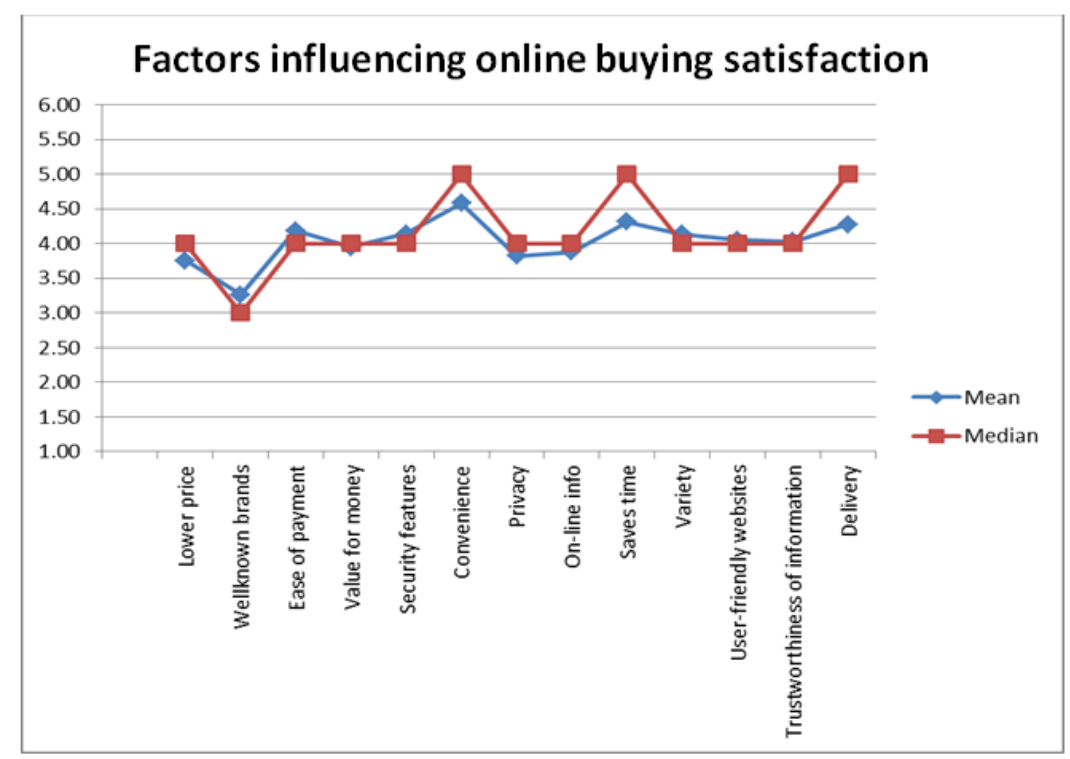

Figure 2: Factors Influencing Online Buying Satisfaction

Subsequently the factors identified in the framework (see Figure 1) were subjected to an exploratory factor analysis to determine if any clear constructs emerge.

\section{Factor Analysis}

An explorative factor analysis was conducted, using principal component extraction and varimax rotation. The Kaiser-Meyer-Olkin Measure of Sampling Adequacy (0.672) and the Bartlett's Test of Sphericity, which was significant $(\mathrm{p}=0.000)$, both indicate that a factor analysis is appropriate.

The analysis identified six factors (final factor loadings are shown in Figure 3), based on the eigenvalue criterion, which explain $63.9 \%$ of the variance. 
Factor Loadings

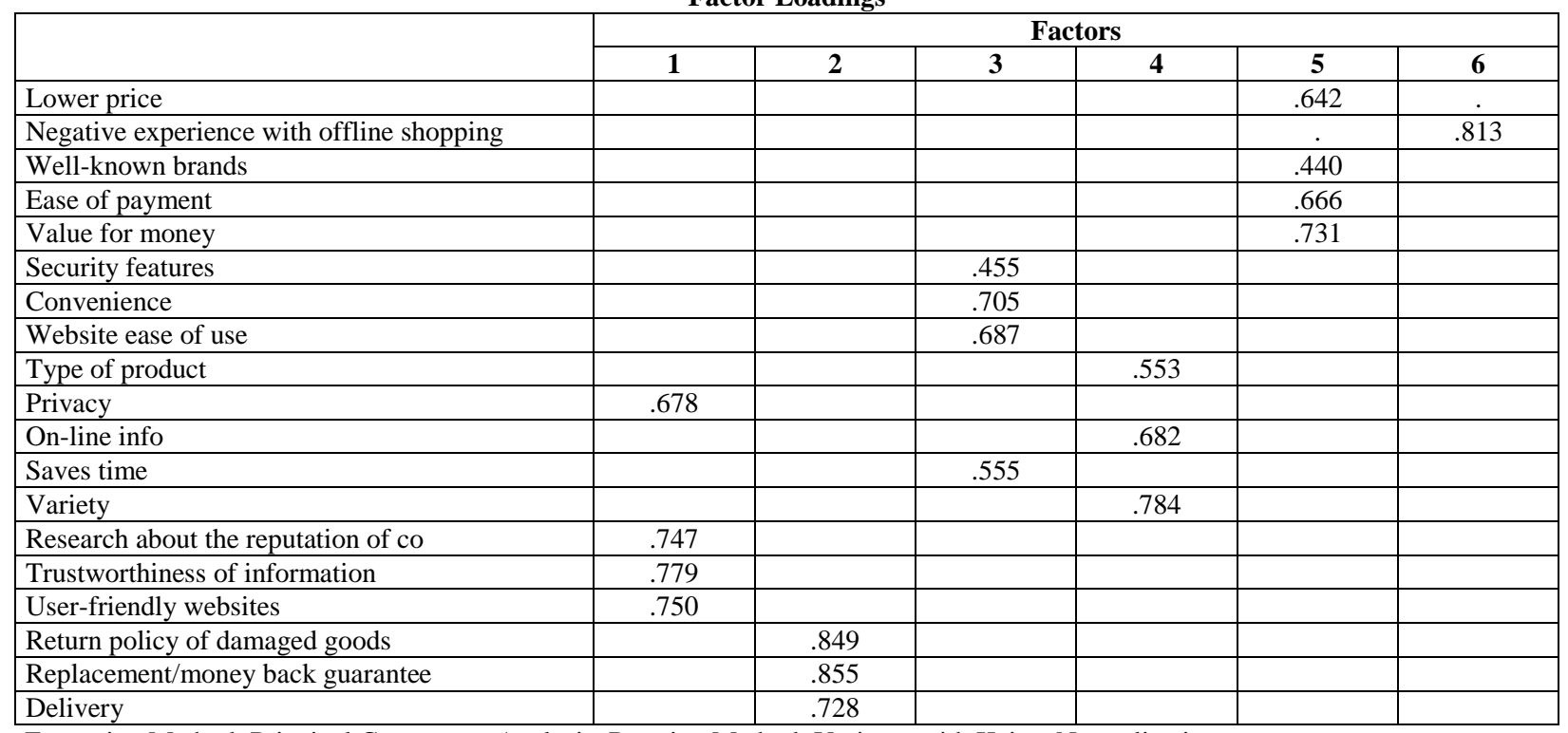

Extraction Method: Principal Component Analysis. Rotation Method: Varimax with Kaiser Normalization.

Figure 3: Six Identified Factors

The sixth factor consisted of only one variable and was not used in subsequent analyses. The other five factors were labelled as security, logistics, convenience, price experience and product variety, respectively.

Using Cronbach alpha, the internal consistency (reliability) for the five factors was found to be 0.779 , $0.810,0.571,0.553$, and 0.591 , respectively. Although loadings for the last three factors were below the threshold of 0.7 , they were deemed satisfactory due to the exploratory nature of this study.

Factor-based scores were subsequently calculated as the mean score of the variables included in each factor for each respondent.

In order to determine the extent to which these factors have an effect on customer satisfaction of online customers, a multiple regression analysis was done with the three statements that were used as proxies for customer satisfaction, respectively:

a) Rating of overall on-line buying experience

b) Intention to buy online again in future

c) Referred someone to an on-line shopping website (word of mouth)

\section{Regression}

The results are shown in Table 2 .

Table 2: Factors Influencing Customer Satisfaction

\begin{tabular}{|l|c|c|c|}
\hline & $\begin{array}{l}\text { Model 1 - Rating of } \\
\text { overall on-line buying } \\
\text { experience }\end{array}$ & $\begin{array}{l}\text { Model 2 - Intention to } \\
\text { buy online again in } \\
\text { future }\end{array}$ & $\begin{array}{l}\text { Model 3 - Referred someone } \\
\text { to an on-line shopping } \\
\text { website }\end{array}$ \\
\hline Security & $.197^{*}$ & -.018 & -.011 \\
Logistics & -.042 & .028 & .054 \\
Convenience & .069 & .122 & .107 \\
Price experience & $.184^{*}$ & $.215^{* *}$ & -.115 \\
Product Variety & .061 & .139 & $.178^{*}$ \\
\hline $\mathrm{R}^{\mathbf{2}}$ & .116 & .098 & .073 \\
\hline $\mathrm{F}(\mathrm{p}$ value $)$ & $2.753(0.022)$ & $2.281(0.052)$ & $1.642(.155)$ \\
\hline
\end{tabular}

Note: Standardized Beta-coefficients are presented. $* \mathrm{p}<0.10, * * \mathrm{p}<0.05$ 
The results indicated that, for each proxy statement, the factors did not result in a model that can be used for predictive purposes as can be seen from the low $\mathrm{R}^{2}$ values. However, it indicated that:

(i) Security and Price experience have an effect on overall online buying experience

(ii) Price experience has an effect on buying online again in the future

(iii) Product Variety has an effect on referring someone to an online shopping website

It thus seems that in order to make the online buying experience as positive as possible, online retailers should pay specific attention to security and price when designing their market offerings. Online shoppers are particularly sensitive to issues such as fraud and theft where credit card purchases are concerned, and these issues should be addressed in market offerings, and particularly on the websites of online retailers. Adequate security, trustworthiness of information, and privacy should be emphasised in all advertisements and websites.

The price experience of online shoppers, when buying from an online retailer, can influence them to either buy from the retailer again in the future or to ignore the retailer in future online shopping. Ease of payment, low prices, and value for money are key factors that online retailers should consider when designing their market offerings. These factors can help online retailers to build long-term relationships with their customers.

Offering a broad variety of products and providing sufficient information about these products will positively influence word of mouth references and it is thus imperative that online retailers do not simply stock and advertise a narrow range of products. Information, which online retailers can provide, includes product types and descriptions, instructions, demonstrations, and product reviews. A broad variety of products and adequate information will ensure positive word-of-mouth references.

\section{CONCLUSION}

Online shopping has increased tremendously in the last few years, but South Africa seems to lag behind most other countries where this type of shopping is concerned. Therefore, the purpose of this research was to investigate the factors which influence customer online shopping satisfaction in South Africa.

The researcher thus developed a model which encompasses factors that could influence customer online buying satisfaction and investigated whether the factors in the model do, in fact, influence the online shopping satisfaction of shoppers in the Gauteng province in South Africa. This model consists of four groups of factors; namely, technology, shopping, product, and logistic factors. It was found that convenience, delivery, and saves time were viewed by customers as the most important reasons for buying online, while well-known brands was viewed as the least important.

The factors identified in the model were subsequently subjected to an exploratory factor analysis and the results identified five important factors or groups of factors which influence online shopping satisfaction; namely, security, logistics, convenience, price experience, and product variety.

The security factor identified in the analysis proved to be a key subcomponent within the technology factors identified in the model, while the convenience and value for money factors identified in the analysis are key subcomponents within the shopping factors identified in the model. The product variety factor identified in the analysis was found to be a key subcomponent within the product factors identified in the model and the logistic factor identified in the analysis can be aligned with the logistic factors identified in the model. These findings therefore confirm the model developed by the researcher.

In order to test the extent to which these factors have an effect on the customer satisfaction of online shoppers, a multiple regression analysis was conducted with three customer satisfaction statements. Although the results did not result in findings that can be used for predictive purposes, it was found that security and price experience have an effect on overall online buying experience, while price experience also has an effect on buying online in the future. The results also indicate that product variety has an influence on referring someone to an online shopping website. These findings offer valuable insight for online retailers in order to design effective market offerings which will convert potential customers into real customers and retain them. 
In order to close the gap between online shopping in South Africa and online shopping in the rest of the world, South African retailers should pay attention to the factors identified in the model. They could use these factors in the design of their websites and advertisements, product descriptions, pricing policies, and delivery methods, resulting in increased online sales, online buying, and online customer satisfaction.

There are numerous opportunities for future research in this area. Comparison studies could be conducted to compare online buying in South Africa to other countries in Africa, Europe, Australia, and America. Research could also be conducted to determine the profiles of consumers in the different LSM groupings in South Africa.

\section{AUTHOR INFORMATION}

Sharon Rudansky-Kloppers is an Associate Professor in the Department of Business Management at The University of South Africa (Unisa). She holds a DCom degree in Business Management and has been lecturing at Unisa for 26 years. Her research interests include business management, consumer behaviour, marketing, and business communication. E-mail: rudans@unisa.ac.za

\section{REFERENCES}

1. $\quad$ A Guide to Business. (2014). Definition of online shopping. Retrieved on 18 March 2014 from http://www.streetdirectory.com/etoday/definition-of-online-shopping-jeljj.html

2. $\quad$ Ahuja, M., Mahlawat, S., \& Masood, R. Z. (2011). Study of Service quality management with SERVQUAL model: An empirical study of GOVT?NGO's eye hospitals in Haryana. Internationally Indexed Journal, 2(2), 310-318.

3. Alam, S. S., \& Yasin, N. M. (2010). An Investigation into the antecedents of customer satisfaction of online shopping. Journal of Marketing Development and Competitiveness, 5(1), 2010.

4. $\quad$ Anonymous. (2013). SA online shopping takes a step backwards. Retrieved on 19 March 2014 from htte://businesstech.co.za/news/internet/40796/sa-online-shopping-takes-a-step-backwards

5. Anonymous (2013). Online shopping taking off in South Africa. Retrieved 4 January 2014 from http://www.ujuh.co.za/news/online-shopping-taking-off-in -south-africa/

6. Bèlanger, F., Hiller, J., \& Smith, W. (2002). Trustworthiness in electronic commerce: The role of privacy, security and site attributes. Journal of Strategic Information Systems, 11, 245-270.

7. Blumberg, B., Cooper, D. R., \& Schindler, P. S. (2011). Business research methods (3rd ed). London: McGraw-Hill Higher Education.

8. Brink, A., \& Berndt, A. (2004). Customer relationship management and customer service. Cape Town: Juta.

9. Byambaa, B., \& Chang, K. (2012). The influence of factors of online purchase on customer satisfaction in Mongolian Airlines. Retrieved on 22 February 2014 from http://www.ipedr.com/vol57/015-ICBMG2012B00031.pdf. DOI: 10.7763/1PEDR

10. Chen, S., Yeh, T., \& Chen, C. (2011). Integration SERVQUAL model and performance control matrix to improve service quality for the hot spring industry. African Journal of Business Management, 5(13), 53785387

11. Cinman, J. SA internet users grow by over 2 million. Retrieved 15 March 2014 from http://www.bizcommunity.com/Article/196/19/97251.html\#more

12. Duncan, F. (2013). Four things South African retailers need to do better online. Retrieved on 19 March 2014 from http://www.moneyweb.co.za/moneyweb-across-the-atlantic/four-things-south-african-retailersneed-to-do-better

13. Emarketing dictionary. (2014). Online store. Retrieved on 19 March 2014 from http://www.emarketingdictionary.com/Internet_Marketing_dictionary_Online_Store_definition.html

14. Goko.C. (2013). Online shopping market grows in South Africa. Retrieved on 20 March 2014 from http://www.bdlive.co.za/business/retail/2013/02/04/online-shopping-market-grows-in-south-africa.

15. Goldstuck, A. (2013) Media future: The fastest growing categories of online sales in South Africa. Retrieved on 15 March 2014 from http://www.marklives.com/2013/07/media-future-the-fastest-growingcategories-of-online-sales-in-south-africa/ 
16. Guo, X., Ling, K. C., \& Liu, M. (2012). Evaluating factors influencing consumer satisfaction towards online shopping in China. Asian Social Science, 8(13), 40-50.

17. Jacobs, B., \& De Klerk, H. M. (2010). Online apparel shopping behaviour of South African professional women: the role of consumers' apparel shopping scripts. Retrieved on 15 March 2014 from http://repository.up.ac.za/handle/2263/15826

18. Kloppers, E. (2013). SA vyf jaar agter met aanlyn inkopies. Kleinhandelaars sal agterstand gou moet inhaal. Sake Rapport., 6 Oktober,4.

19. Koble, M. (2014). Definition of an online shop. Retrieved on 19 March 2014 from http://www.ehow.com/about_6607400_definition-online-shop.html

20. Maake, M., \& Shevel, A. (2013). SA lagging behind brics peers in online retail. Retrieved on 15 March 2014 from http://www.bdlive.co.za/business/retail/2013/01/27/sa-lagging-behind-brics-peers-in-onlineretail

21 Markovic, S., Raspor, S., \& Segaric, K. (2010). Does restaurant performance meet customers’ expectations? An assessment of restaurant service quality using a modified DINESERV approach. Tourism and Hospitality Management, 16(2), 181-195

22. North, E. G., Mostert, P. G., \& Du Plessis, P. J. (2003). Cybershopping: concerns of the South African consumer. Tydskrif vir Gesinsekologie en Verbruikerswetenskappe, 31, 58-66.

23. Prasad, M. D., \& Shekar. B. R. (2010) Development of railqual: A service quality scale for measuring indian railway passenger services. Management Science and Engineering, 4(3), 87-94. Retrieved on 20 February 2014 from Http://50.22.92.12/Index.Php/Mse/Article/Viewfile/1345/1364

24. Sauerwein, E., Bailom, F., Matzler, H., \& Hinterhuber, H. (1996). The Kano model: How to delight your customers. IX International Working Seminar on Production Economics, Innsbruck/Igls/Austria. Preprints, 1, 313-327. Retrieved on 22 February 2014 from http://faculty.kfupm.edu.sa/CEM/bushait/CEM_515082/kano/kano-model2.pdf

25. Schaupp, L. C., \& Bèlanger, F. (2005). A conjoint analysis of online consumer satisfaction. Journal of Electronic Commerce Research, 6(2), 95-111.

26. Shaikh, U. A. A. (2009). Impact of service quality on customer satisfaction: Evidence from the restaurant industry in Pakistan. The Business Review, Cambridge, 13(2), 178-185.

27. South Africa.info. (2014). Gauteng province, South Africa. Retrieved on 4 May 2014 from http://www.southafrica.info/about/geography/gauteng.htm\#ixzz31TxcC3g6

28 Tustin, D. H., Ligthelm. A. A., Martins, J. H., \& Van Wyk, H. J. (2010). Marketing research in practice. South Africa: Unisa Press.

29. Watson, L. (2013) Slimfone bly koop-koning. Sake Rapport. 18 August 2013.

30. Wealthwisemag.com. (2013) Online shopping trends revealed for South Africa. Retrieved on 19 March 2014 from http://www.wealthwisemag.com/online-shopping-trends-revealed-for-south-africa/

31. Wilson, C. (2013). SA's online spending habits revealed. Retrieved on 17 November 2013 from http://www.techcentral.co.za/sas-online-spending-habits-revealed/41491/

32. Zeithaml, V. A., Bitner, M. J., \& Gremler, D. D. (2006). Services marketing: Integrating customer focus across the firm (4th ed.). New York: McGrawHill. 